\title{
Ecuador: Use commercial marketing to increase sustainability
}

Frontiers in Reproductive Health

Follow this and additional works at: https://knowledgecommons.popcouncil.org/departments_sbsr-rh

Part of the Demography, Population, and Ecology Commons, and the Pharmacoeconomics and Pharmaceutical Economics Commons

How does access to this work benefit you? Let us know!

\section{Recommended Citation}

"Ecuador: Use commercial marketing to increase sustainability," FRONTIERS OR Summary. Washington, DC: Population Council, 2001. 


\section{Ecuador Cost Analysis}

OR Summary 19

\section{Use Commercial Marketing to Increase Sustainability}

\begin{abstract}
An analysis of CEMOPLAF's product marketing program found that net revenue is the best measure of sales performance, since it takes product costs into account. Sales agents in large cities had the largest sales and generated most of the profits, whereas sales agents in smaller cities had lower sales volume. Program managers should set up a routine financial analysis system so that they can monitor product sales, profits, and unit costs for sound decisionmaking.
\end{abstract}

\section{Background}

Many non-governmental organizations sell contraceptives through retail outlets in order to generate income and expand access to these products. In 1998 Centro Médico de Orientación y Planifación Familiar (CEMOPLAF) employed 25 sales agents in 14 cities throughout Ecuador. These agents sold 36 products, including 19 contraceptive methods and home pregnancy tests. Products were sold to pharmacies, physicians, other distributors, and non-traditional outlets such as liquor stores and hotels.

Contraceptive sales were CEMOPLAF's largest source of revenue in 1997, accounting for 36 percent of total revenues. Sales had grown rapidly during 1996-97, but CEMOPLAF managers did not know whether product sales were profitable.

With support from the Population Council and its partner Family Health International, CEMOPLAF made a detailed analysis of product sales income and costs during 1998. Profitability was calculated by sales agent and region and for the entire program.

\section{Findings}

- Overall, the product sales program generated a 10 percent net profit (sales revenue minus total costs). The cost of goods sold accounted for 70 percent of total costs. Other costs such as personnel, program overhead, and advertising accounted for an additional 20 percent of costs (see Figure 1).

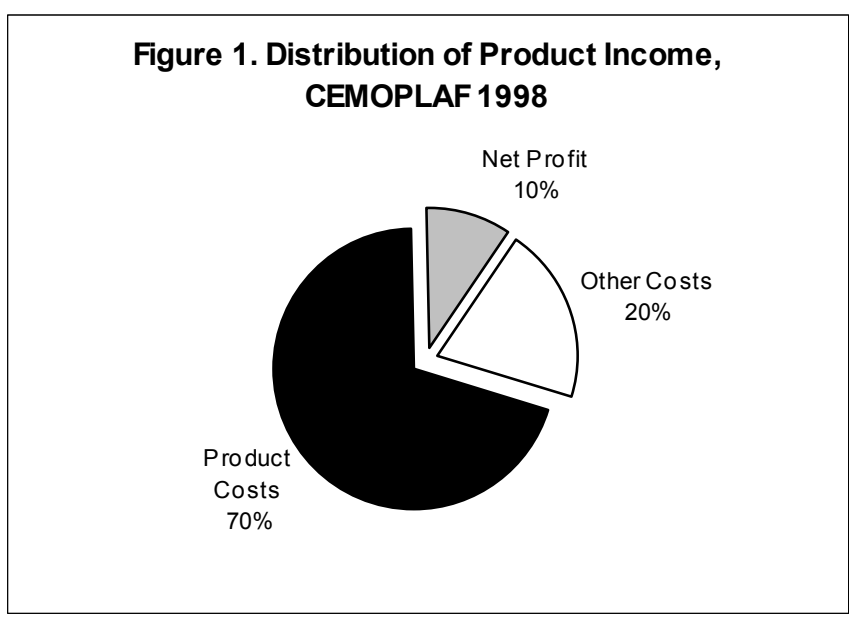

- More than one-third of sales revenues came from a single product: the Protektor condom. These revenues resulted from a high sales volume. The per-item profit on condoms was 
low because their sales price was close to their actual price. Oral contraceptives, injectable contraceptives, and home pregnancy tests also had high unit sales. Clamox, a vaginal cream, had the highest per-unit profit, while Gynera CD, an oral contraceptive, was the most profitable contraceptive product per unit.

- Half of the 25 sales agents produced nearly all of the profits; most of these agents worked in Quito and Guayaquil. Most sales agents working in smaller cities earned small net profits or actually lost money (see Figure 2). This difference is due to the larger sales volume in big cities. Also, the mix of products sold had an effect on net profits due to differences in the profit margins.

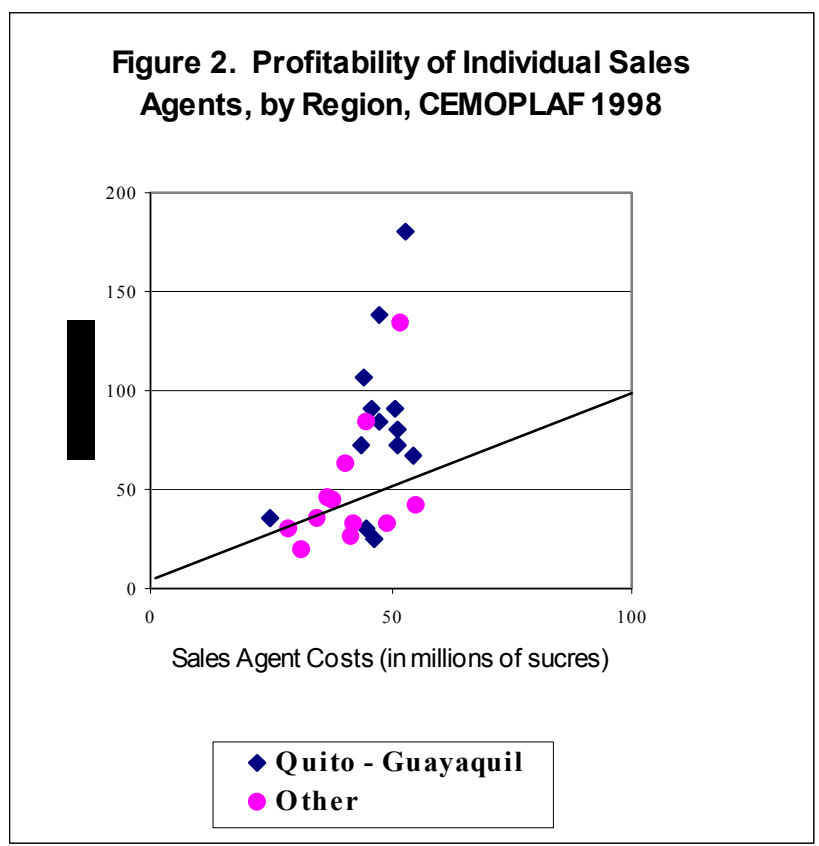

\section{Policy Implications}

- Product sales programs should routinely analyze information on net revenues by product. Managers and sales agents can use this information to analyze profitability and track sales volumes and trends as well as unit profit margins.

- Agencies should use net revenue (sales minus product costs) to assess sales performance, rather than gross revenue, because product costs are a major factor affecting profit margins.

- Program managers should evaluate alternative ways to compensate sales agents. Sales agents who are provided with substantial bonuses based on net revenue may have greater incentive to sell more products than those who receive fixed salaries and small sales bonuses.

- In areas where the sales volume is too low to generate a net profit, managers should consider measures to ensure profitability such as providing incentives to agents to increase sales, eliminating some sales agent positions, consolidating sales areas, or raising prices.

- CEMOPLAF adopted the financial management procedures used in the study. It also modified and expanded its product line on the basis of the financial analysis.

de Vargas, Teresa and John H. Bratt. 2000. A Profitability Analysis of the CEMOPLAF Social Marketing Program. Washington, D.C.: Population Council. For more information contact: Population Council, Escondida No. 110, Col. Villa Coyoacán, 04000 México, D.F., Mexico.Tel.: 52-5554-0388; Fax: 52-5554-1226; E-mail: disemina@popcouncil.org.mx .

This study was funded by the U.S. AGENCY FOR INTERNATIONAL DEVELOPMENT (USAID) under Cooperative Agreement Number HRN-A-00-98-00012-00. 